\title{
MUSTAHIQ ZAKAT FITRAH DAN RELEVANSINYA DENGAN KEWAJIBAN MENUNAIKANNYA BAGI SETIAP MUSLIM (Telaah Pendapat Imam Malik W. $178 \mathrm{H}$ )
}

\author{
Mushthafa \\ Sekolah Tinggi Agama Islam Solok Nan Indah \\ e-mail: akhy.thafa@gmail.com
}

\begin{abstract}
It is different from the opinion of other religious scholars who state that mustahiq of zakat fitrah is the same as mustahiq of rakat mall as it is Allah's command in QS. Al-Taubah verse 60. Imam of the Maliki School and some Malikiyah scholars argued that mustahiq of zakat fitrah is a indigent and poor group, this is based on instructions of Rasulullah $S A W$. The existence of ikhtilaf in providing group boundaries for this mustahiq of zakat fitrah will be very interesting to be investigated further, especially if it is associated with the obligation to carry out the order zakat fitrah for every Muslim and wisdom contained in the order zakat fitrah.
\end{abstract}

Kata kunci: Zakât fitrah, Mustahiq zakât fitrah, Imâm Mâlik.

\section{PENDAHULUAN}

$Z$ akât fitrah disamping memiliki dimensi sosial yang terkandung dalam pensyari'atannya, zakat fitrah juga merupakan ibadah mahdhah yang diwajibkan bagi orang-orang Islam, yang diperuntukan bagi kepentingan seluruh masyarakat. Sebagaimana diketahui pada setiap Hari Raya Idul Fitri, setiap orang Islam baik laki-laki maupun perempuan, besar kecil, merdeka atau hamba, diwajibkan membayar zakat fitrah sebanyak 3,5 liter atau satu sha dari makanan yang mengenyangkan menurut daerah tiap-tiap tempat.

Zakat fitrah bagi umat Islam bukan hanya sebuah rutinitas yang berdimensi sosial yang mengiringi ibadah puasa di bulan Ramadhan, akan tetapi lebih dari itu zakat fitrah merupakan kewajiban yang diperuntukkan bagi terwujudnya kesempurnaan ibadah puasa yang telah ditunaikan.

Untuk mendapatkan hikmah dari disyariatkannya zakât fitrah, pelaksanaannya tentu harus mengacu pada ketentuan syariat, diantaranya dalam hal kepada siapa zakât fitrah itu diberikan. Berkenaan dengan hal ini Imâm al-Syâfi'i berpendapat bahwa zakât fitrah itu kepada ashnâf yang delapan. Namun ulama lain, seperti Imâm Mâlik dan sebagian dari ulama Malikiyah berpendapat lain, begitu juga Imâm Abu Hanifah mengatakan bahwa dalam situasi dan kondisi tertentu, maka zakât boleh diberikan kepada satu atau beberapa golongan saja.

Selanjutnya Yusuf al-Qardhawi mengatakan bahwa dalam kitabnya, bahwa Ibnu Qudamah al-Muqdisi berpendapat bahwa yang menjadi mustahiq zakât fitrah itu adalah kelompok fakîr dan miskîn saja, tidak 
untuk kelompok yang lainnya kecuali kelompok tersebut juga memiliki sifat fakir dan miskin. Namun apabila di suatu daerah tidak ada orang fakir dan miskin, maka pendistribusiannya dipindahkan ke daerah terdekat dengan biaya yang diambil dari muzakkî, bukan dari harta zakat yang akan didistribusikan. Pendapat ini juga sejalan dengan pendapat Imâm Ahmad, Ibnu Qayyim dan gurunya Ibnu Taimiyah.

Berdasarkan uraian di atas, mustahiq zakât fitrah menjadi menarik untuk diteliti lebih jauh terhadap dua kelompok pendapat yang mengemuka, terutama terhadap pendapat minoritas yang hanya mengkhususkan pada dua ashnâf saja, yaitu kelompok fakir dan miskîn. Urian dalam tulisan ini setidaknya ingin mengemukakan secara lebih mendalam terkait dengan zakât fitrah, mustahiq zakât fitrah, kewajiban zakât fitrah menurut pendapat Imâm Mâlik dan Malikiyah dan relevansinya dengan pencapaian nilai yang terkandung di dalam pensyariatannya, dengan berdasarkan dalil naqli dan aqli.

\section{METODE PENELITIAN}

Adapun metode penelitian dalam tulisan ini adalah library research (studi kepustakaan) dengan pendekatan deskriptif analitis, yaitu mendeskripsikan tentang objek kajian dengan menganalisis secara mendalam kemudian menyimpulkan hasil analisis tersebut. Adapun sumber yang digunakan adalah buku ataupun karya ilmiah yang merujuk kepada tema/permasalahan yang dibahas.

\section{BIOGRAFI IMÂM MÂLIK}

'Abdullâh Mâlik ibn Anas ibn Mâlik ibn Abi Amir Ibn 'Umar bin al-Haris adalah nama lengkap dari Imâm Mâlik. Tempat kelahirannya diketahui bernama Zulmarwah di sisi utara Kota Madinah. Beliau sempat tinggal untuk sementara waktu di al-Akik, untuk kemudian menetap tinggal di Kota Madinah alMunawwarah (Al-Syurbasi, 1991: 72-73).

Ayah Imam Malik adalah Anas Ibn Malik Ibn Abi Amir Ibn Abi Al-Haris Ibn Sa'ad Ibn Auf Ibn Ady Ibn Malik Ibn Jazid. Ibunya bernama Siti Aliyah binti Syuraik Ibn Abdul Rahman Ibn Syuraik Al-Azdiyah. Ada riwayat yang mengatakan bahwa Imam Malik berada dalam kandungan ibunya selama 2 tahun ada pula yang mengatakan sampai 3 tahun (Yanggo, 1997: 105). Pada suatu riwayat disebutkan bahwa Imâm Mâlik dilahirkan dari kalangan keluarga yang ahli dalam bidang ilmu hadits dan dibesarkan di lingkungan masyarakat yang banyak disibukkan dengan hadits dan atsar (Rahman, 1995: 224).

Sehingga tidak mengherankan jika semenjak usia bermain, Malik kecil telah belajar membaca dan menghafal al-Qur'an serta Sunnah Rasulullâh SAW. Ketika beranjak dewasa, beliau lebih menyibukkan diri dengan banyak belajar kepada para ulama dan fuqaha Madinah, dengan cara mempelajari dan mendalami pengetahuan yang didengar, menghafalkan, dan mengambil setiap kaidah-kaidah penting dari setiap ilmu dari masing-masing ulama. Sehingga terkait dengan kepandaian Imâm Mâlik dalam bidang ilmu hadits tidak dapat terbantahkan, demikian karena telah banyaknya pernyataan para ulama tentang itu, dan telah dibuktikan dengan telah dihimpun dan disusunnya haditshadits riwayat Imâm Mâlik dalam sebuah kitab yang bernama al-Muwatta

(AlSyurbasi, 1991: 73-74). 
Selanjutnya berdasarkan catatan sejarah, Imâm Mâlik dikenal sebagai salah seorang pendiri mazhab fiqh yang beraliran hadîts di Hijaz. Metode istinbâth dan pemikirannya dalam pembentukan mazhab dapat diketahui dari para murid ('Ulama Malikiyah) yang telah tertuang dalam kitab-kitab fiqh dan hadits. Kemudian setelah Imâm Mâlik menjabat sebagai Imâm besar dalam segala urusan agama di kota Madinah, beliau wafat diusia 87 tahun, diketahui pada waktu itu bertepatan dengan tanggal 10 Rabiul Awwal 178 Hijrah. Jenazah beliau dimakamkan di luar kota Madinah, tepatnya suatu daerah yang bernama Baqi'.

\section{ZAKAT FITRAH}

1. Pengertian dan Dasar Hukum Zakat Fitrah

Zakat berasal dari akar kata zakâ, yang mengandung beberapa arti seperti membersihkan, tumbuh, dan berkah. Seperti firman Allah SWT dalam surat al-Nûr ayat 21:

- ....

... dan tetapi Allah membersihkan siapa yang dikehendakinya, dan Allah maha mendengar dan maha mengetahui (QS. Al-Nûr [24]: 21).

Digunakan kata zakâ dengan arti membersihkan, karena memang diantara hikmah diwajibkannya zakat adalah untuk membersihkan jiwa dan harta orang yang berzakat. Secara istilah zakat diartikan dengan "Pemberian tertentu dari harta tertentu kepada orang tertentu menurut syarat-syarat yang telah ditentukan" (Syarifuddin, 2003) yang diperuntukkan bagi fakir miskin dan para mustahiq lainnya sebagai tanda syukur atas nikmat Allah swt.dan untuk mendekatkan diri kepada-Nya, serta untuk membersihkan diri dan hartanya (Al-Qardhawi, 1999: 999).

Secara garis besar, zakât dalam pensyari'atannya diklasifikasikan kepada dua kelompok yaitu zakât mâl atau yang biasa disebut dengan zakât harta, dan zakât jiwa atau yang biasa disebut dengan zakât fitrah.

Zakat fitrah ialah zakat diri yang diwajibkan atas setiap individu muslim laki-laki dan perempuan, kecil ataupun besar, merdeka ataupun budak (Sabiq, 1978: 126). Kata Fitrah yang ada merujuk pada keadaan manusia saat baru diciptakan sehingga dengan mengeluarkan zakat ini manusia dengan izin Allah akan kembali fitrah. Berkenaan dengan adanya kewajiban zakat fitrah ini dapat didasarkan pada hadits riwayat Ibnu Umar berikut ini:

$$
\begin{aligned}
& \text { حدثني يهيى عن مالك عن نافع عن عبد الله بن } \\
& \text { عمر :أن رسول الله صلى الله عليه و سلم فرض } \\
& \text { زكاة الفطر من رمضان على الناس صاعا من تمر أو } \\
& \text { صاعا من شعير على كل حر أو عبد ذكر أو أنثى } \\
& \text { من المسلمين. }
\end{aligned}
$$

Telah menceritakan kepadaku Yahya dari Malik dari Nâfi' dari Abdullah ibn Umar sesungguhnya Rasulullah SAW telah memfardhukan zakat fitri dari bulan ramadhan sebanyak satu sha' kurma atau satu sha' gandum atas orang merdeka atau hamba sahaya laki- 
laki atau perempuan yang beragama Islam.

Hadits tersebut menjelaskan kewajiban semua umat Islam untuk mengeluarkan zakat fitrah sejak awal datangnya bulan ramadhan berikut ketentuan kadar zakat yang harus dibayarkan. Adapun penjelasan hadits yang berkenaan dengan sampai kapan waktu pelaksanaannya dapat dilihat pada kitab muwaththa' tepatnya pada hadits riwayat Ibnu Abbas berikut ini:

$$
\begin{aligned}
& \text { عَنْ عِكِكِمَةَ عَنِ ابْنِ عَبَّاسِ قَالَ فَرَضَ رَسُولُ اللَّهِ }
\end{aligned}
$$

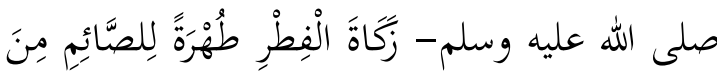

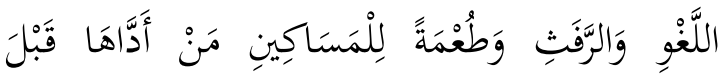

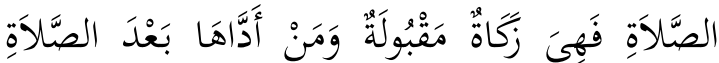

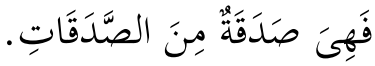

Dari Ikrimah dan Ibnu Abbas berkata: Rasulullah SAW telah memfardhukan zakat fitri untuk mensucikan orang yang berpuasa dari ucapan sia-sia dan tidak senonoh, dan untuk memberi makan fakir miskin. Siapa yang memberikannya sebelum keluar untuk shalat idhul fitri, maka yang demikian adalah zakat fitri, namun apabila diberikan sesudah selesai shalat idhul fitri, maka yang demikian itu hanyalah sedekah sebagaimana sedekah-sesekah biasa.

Berdasarkan pada hadits riwayat Ibnu Umar tersebut di atas, setidaknya telah dijelaskan oleh Rasulullah SAW tentang batas waktu menunaikan zakat fitrah tersebut yakni sebelum shalat Idhul Fitri dilaksanakan, disamping hikmah yang terkandung dalam menunaikan kewajiban zakat tersebut.

Maka berdasarkan penjelasan hadits tersebut di atas dapat dipahami bahwa pada prinsipnya setiap muslim diwajibkan untuk mengeluarkan zakat fitrah untuk dirinya, keluarganya dan orang lain yang menjadi tanggungannya baik orang dewasa, anak kecil, laki-laki maupun wanita. Sehingga dapat disimpulkan apa syarat yang menyebabkan individu wajib membayar zakat fitri adalah: pertama, individu yang mempunyai kelebihan makanan atau hartanya dari keperluan tanggungannya pada malam dan pagi hari raya; Kedua, Anak yang lahir sebelum matahari jatuh pada akhir bulan Ramadan dan hidup selepas terbenam matahari; Ketiga, memeluk Islam sebelum terbenam matahari pada akhir bulan Ramadhan dan tetap dalam Islamnya; Keempat, seseorang yang meninggal selepas terbenam matahari akhir bulan Ramadhan.

2. Mustahiq Zakât Fitrah

Adapun kelompok yang berhak menerima zakat fitrah, terdapat beberapa pendapat, diantaranya:

a. Pendapat yang mewajibkan dibagikannya pada asnaf yang delapan dengan rata, ini adalah pendapat yang masyhur dari mazhab Imam al-Syafi'i.

b. Pendapat yang memperkenankan membagikannya kepada asnaf yang delapan dan mengkhususkannya kepada golongan fakir. Ini adalah pendapat jumhur, karena zakat fitrah itu adalah zakat juga sehingga masuk pada keumuman ayat 60 dari surat al-Taubah.

c. Zakat fitrah itu dibagikan khusus untuk fakir miskin saja. Pendapat ini dipegang oleh sebagian Malikiyah, Ibnu Qayyim, Ibnu Taimiyah, Imam Hadi, Qashim dan Abu Thalib, 
karena zakat fitrah itu khusus untuk membersihkan diri pribadi dan memberi makan orang miskin (Hasan, 2006: 112).

Menurut Mazhab al-Syâfi'i, yang berhak menerima zakat fitrah adalah sama dengan kelompok-kelompok yang herhak menerima zakat mâl, sebagaimana yang telah ditetapkan Allah SWT sebagaimana termaktub dalam firmanNya al-Qur'ân surat alTaubah berikut:

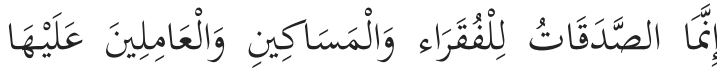

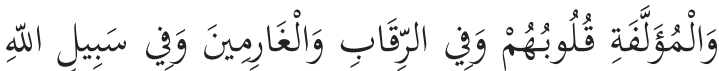

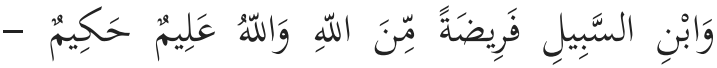

$$
\begin{aligned}
& -7 \text {. }
\end{aligned}
$$

Sesungguhnya zakat itu hanyalah untuk orang-orang fakir, orang miskin, amil zakat, yang dilunakkan hatinya (mualaf), untuk (memerdekakan) hamba sahaya, untuk (membebaskan) orang yang berhutang, untuk jalan Allah dan untuk orang yang sedang dalam perjalanan, sebagai kewajiban dari Allah. Allah Maha Mengetahui, Maha Bijaksana QS. Al-Taubah [9]: 60.

Ayat tersebut menisbatkan bahwa kepemilikan semua zakat oleh kelompokkelompok tersebut dinyatakan dengan pemakaian huruf lam yang dipakai untuk menyatakan makna "kepemilikan", kemudian masing-masing kelompok memiliki hak yang sama, demikian karena dihubungkan dengan huruf waw yang menunjukkan kesamaan tindakan. Oleh karena itu, semua bentuk zakat adalah menjadi milik kelompok ini, dengan hak yang sama (Al-Zuhaili, 1997). Adapun ashnaf delapan dimaksud dapat diuraikan secara singkat sebagai berikut:

a. Orang fakir (al-fuqarâ')

Al-fuqarấ adalah bentuk jamak dari kata al-fâqir, yang oleh ulama Syafi'iyah dan Hanbali dipahami sebagai kelompok yang tidak memiliki harta benda dan juga tidak memiliki pekerjaan yang dapat mencukupi kebutuhan sehariharinya. Orang ini tidak memiliki pendamping hidup, ayah-ibu, dan keturunan yang dapat memenuhi kebutuhan hidupnya, baik untuk memenuhi kebutuhan makanan, pakaian, ataupun tempat tinggalnya.

b. Orang-orang miskin (al-masâkîn)

Kata al-miskin adalah bentuk mufrad dari kata al-masâkîn yang bermakna kelompok orang-orang miskin. Kelompok ini adalah mereka yang tidak dapat memenuhi standar kebutuhan hidupnya meskipun mereka telah bekerja dan berusaha untuk itu. Dengan kata lain dari segi hitungan kuantitas mereka ini tidak mampu memenuhinya, baik dari segi pemenuhan kebutuhan makanan, pakaian, dan ataupun tempat tinggal.

Bila kita telusuri lebih lanjut, ditemukan pengertian tentang fakir dan miskin ini banyak sekali. Oleh at-Tabari disimpulkan ada sembilan fakir dan miskin:

1) Orang miskin adalah orang yang mempunyai sebagian harta untuk menutupi kebutuhannya, sedangkan fakir adalah orang yang tidak mempunyai sesuatu.

2) Kelompok fuqarâ dan masâkîn adalah dua kelompok orang yang 
sama pada masalah tingkat pemilikkannya, meskipun mereka berbeda dalam simbulnya.

3) Secara lahiriyah kata miskin memang bukan dimaksudkan untuk menyebut fakir, keduanya memang dua kelompok yang berbeda, dan perbedaan keduanya nyata, bahwa kelompok yang satu (fakir) lebih memerlukan daripada orang miskin.

4) Orang miskin adalah orang yang memerlukan bantuan, tetapi tetap menjaga diri dari meminta-minta, sedangkan fakir adalah orang yang meminta-minta.

5) Orang miskin adalah mereka yang memiliki tempat berteduh untuk tinggal dan mempunyai pelayan yang tingkatan ekonominya lebih tinggi dari pada fakir, sedangkan orang fakir tidak punya apa-apa.

6) Fuqara adalah sebagian orang yang berhijrah, sementara Masakin adalah sebagian orang Arab yang tidak ikut berhijrah.

7) Orang-orang miskin adalah yang cukup kenyang dan mempunyai tempat tinggal, ia tidak memintaminta, sedangkan orang-orang fakir adalah sebaliknya.

8) Orang-orang miskin adalah orang yang meminta-minta, sedangkan fakir adalah orang-orang miskin yang tidak punya.

9) Fakir adalah bagian orang-orang miskin yang tidak punya, sedangkan miskin adalah bagian orang-orang ahli kitab yang tidak punya (Hafidhuddin, 2014: 35).

Meskipun ada beberapa pengertian fakir miskin yang berkisar antara tidak punya, dan mempunyai tetapi tidak cukup, maka al-Maraghi berpendapat, meskipun mereka berbeda simbulnya, tetapi dari segi keadaan keperluan untuk mencukupi kebutuhannya, keduanya sama saja, tidak ada perbedaan antara keduanya. Demikian juga Muhammad Jawad alMugniyah, mengatakan meskipun perbedaan antara fakir dan miskin terletak antara meminta dan tidak meminta, namun apabila yang menjadi pegangan soal memenuhi kehendaknya, maka keduanya tidak ada perbedaannya. Dengan kata lain mereka hanya berbeda sifatnya, tetapi tidak berbeda dari segi jenisnya, yaitu jenis kelompok orang yang tidak dapat memenuhi kebutuhannya

c. Pengurus Zakat (al-'âmilin alaihâ)

'Amil Zakat adalah kelompok orang yang telah ditunjuk dan ditetapkan oleh pemimpin pemerintahan yang sah, dengan tujuan untuk mengurus segala persoalan zakât, mulai dari menghimpun, memelihara, mendistribusikan, mengelola, dan memberdaya gunakan zakât, serta tugas-tugas lain yang ada hubungannya dengan zakât.

d. Orang yang ditundukkan hatinya (al-mu'allafah qulûbuhum)

Muallaf secara leksikal berarti orang-orang yang dijinakkan hatinya untuk tetap berada dalam Islam. Dari berbagai kitab tafsir, yang dimaksud di sini adalah mereka yang baru masuk Islam dan memerlukan masa pemantapan dalam ke-Islam-annya. Dalam kitab tafsirnya Muhammad Rasyid Ridha menguraikan cakupan makna dari 
kata muallaf ini menjadi enam kelompok, berikut ini:

1) Tokoh atau pemuka-pemuka umat Islam yang berpengaruh di kalangan nonmuslim yang diduga kuat dapat mempengaruhi dan mengajak nonmuslim masuk ke dalam Islam. Dana zakat yang diberikan kepada kelompok ini diharapkan mampu memudahkan dakwahnya.

2) Tokoh atau pemuka muslim yang baru masuk Islam (masih lemah imannya), sedangkan mereka ini memiliki pengaruh yang sangat kuat di lingkungannya. Pemberian zakat pada kelompok ini diharapkan mampu memantapkan hati mereka dalam memeluk Islam.

3) Umat Islam yang tinggal di perbatasan negeri nonmuslim, dan keberadaan mereka ini dapat melindungi umat muslim lainnya dari gangguan musuh.

4) Kelompok umat Islam yang memiliki pengaruh besar dalam penerimaan dan penghimpunan zakat dan disegani oleh kelompok-kelompok yang enggan atau inkar membayar zakat.

5) Golongan atau kelompok nonmuslim yang tunduk atau terbuka hatinya dengan nilai-nilai keislaman. Diberikan zakât diharapkan mampu membuka hati dan kesungguhannya untuk memeluk Islam.

6) Golongan atau kelompok nonmuslim yang sangat berpotensi berbuat buruk terhadap umat Islam. Pemberian zakât pada kelompok ini diharapkan mampu memberhentikan segala tindakan keburukan mereka terhadap umat Islam.

e. Memerdekakan Budak (fi al-riqâb)

Riqâb berarti perbudakan, didahului dengan lafaz fî, maka yang dimaksud disini adalah untuk kepentingan memerdekakan budak, baik dengan membeli budak-budak untuk kemudian dimerdekakan, atau memberi dana zakat untuk kepentingan menebus dirinya dari perbudakan.

f. Orang yang terlilit hutang (alghârimîn)

Kata al-ghârimîn maknanya adalah mereka yang dihimpit banyak utang dan tidak memiliki kemampuan untuk melepaskannya kecuali setelah mendapat bantuan dari luar dirinya. Menurut mazhab Hanafi, orang yang berutang adalah orang yang betul-betul memiliki utang dan tidak memiliki apa-apa selain utangnya itu.

g. Orang yang berjuang di jalan Allah (fì sabîlillâh)

Kata sabîlillah berarti "jalan Allah". Apabila didahului dengan lafaz fî maka mengandung arti untuk keperluan menegakkan agama Allah SWT. Pada waktu perang, fîsabîlillâh diartikan dengan biaya pasukan dan perlengkapan selama dalam peperangan. Sedangkan dalam situasi yang lain, lafaz tersebut bermakna segala usaha yang bertujuan untuk menegakkan syiar Islam.

h. Orang yang sedang dalam perjalanan (ibnu al-sabîl)

Ibnu sabil maksudnya adalah orang yang berpergian (musâfir) 
untuk melaksanakan suatu hal yang baik (thâ'ah). Maksudnya adalah kelompok orang ini akan sangat sulit dan bahkan tidak dapat mencapai tujuan dari perjalanannya, jika tidak mendapat bantuan dari orang lain.

Jumhur fuqaha sepakat bahwa zakat tidak boleh diberikan kepada selain kelompok yang telah diuraikan di atas. Demikian didasarkan pada ungkapan awal ayat 60 surat al-Taubah yang diungkapkan dengan kata innamâ yang mengandung makna pembatasan dan penetapan. Menetapkan depalan kelompok yang telah disebutkan dan sekaligus menafikan kelompok-kelompok lain yang tidak disebutkan didalamnya.

\section{MUSTAHIQ ZAKAT MENURUT IMAM MALIK}

FITRAH

Imam Mâlik dan sebagian 'Ulama Malikiyah berpendapat bahwa kelompok yang menjadi mustahiq zakat fitrah itu adalah kelompok mereka yang tergolong fuqarâ dan masâkîn saja. Pendapat ini didasarkan pada hadits riwayat sahabat Ibnu 'Umar, sebagaimana yang telah dinukilkan dalam kitab mawâhib al-jalîl li syarh mukhtashar al-khalîl:

قوله صلى الله عليه وسلم: "أغنوهم" يعني المساكين عن طواف هذا اليوم رواه البيهقي وابن سعد في الطبقات هذا اللفظ وروي أغنوهم عن الطلب في هذا اليوم وروي أغنوهم في هذا اليوم

"Sebagaimana sabda Rasulullah SAW: kayakanlah (cukupkanlah keperluan) mereka (sehingga mereka) tidak berkeliling lagi (untuk meminta-minta) di hari ini (HR. Baihaqi) dan dari riwayat Ibnu Sa'd disebutkan kayakanlah mereka (sehingga mereka) tidak meminta-minta pada hari ini, dan diriwayat yang lain disebutkan, kayakanlah mereka pada hari ini".

Hadits tersebut di atas dipahami dengan makna penuhilah kebutuhan mereka yang tergolong fakir dan miskîn. Adapun bentuk upaya pemenuhan tersebut sehingga kelompok mereka ini tidak lagi meminta-minta pada hari raya 'idul fitri adalah dengan mendistribusikan zakât fitrah kepada mereka sebelum melaksanakan shalat 'idul fitri (AlDamsyiqi, 1997).

Istinbâth hukum Imâm Mâlik tentang siapa yang berhak menerima zakât fitrâh ini dapat diketahui berdasarkan ungkapan syarah ulama malikiyah terhadap kitab Imam Malik dalam berbagai kitab fiqhnya, diantaranya sebagaimana yang termaktub dalam kitab figh al-'ibâdât 'ala al-mazhab al-maliki berikut ini :

تصرف صدقة الفطر إلى الفقراء والمساكين. لا العاملين عليها ولا المؤلفة قلوبهم ولا غيرهم إلا إذا كانوا فقراء أو ويشترط فيمن تعطى له صدقة الفطر : الحرية الإسلام

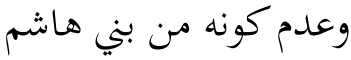

Zakat fitrah diberikan kepada orang-orang fakir dan miskin, bukan diberikan untuk amil zakat, muallaf dan kelompok lainnya, kecuali (kelompok lainnya) mereka itu dalam kategori fakir atau miskin. Dan disyaratkan kepada penerima zakat fitrah itu adalah (fakir dan miskin) yang merdeka, beragama Islam, dan bukan dari keturunan Bani Hasyim ('Abîd, n.d: 298).

Pendapat tentang mustahiq zakat fitrah tersebut sejalan dengan petunjuk Nabi dalam hadits riwayat Ibnu 'Abbas yang 
menyatakan bahwa zakat fitrah itu diperuntukkan khusus bagi kaum fakir dan miskîn saja, sebagai takhshish dari apa yang termaktub dalam firman Allah SWT dalam surat al-Taubah ayat yang ke-60 dengan dalil:

1. Sabda Rasûlullâh SAW: "thu'matu li almasâkîn" (makanan yang diperuntuk bagi orang-orang miskin) yang terdapat dalam matan hadits Ibnu 'Abbas ra. (alShiddiqi, 1997).

2. Ashnâf setelah fuqarâ' dan masâkîn khusus untuk mustahiq zakat harta (Aziz, 2003).

Lebih lanjut Imâm Mâlik menjelaskan bahwa yang dimaksud dengan fakir itu adalah orang yang tidak mempunyai bekal untuk berbelanja selama satu tahun dan juga tidak memiliki kemampuan untuk memenuhi kebutuhan keluarganya. Adapun yang disebut miskin adalah mereka yang keadaan ekonominya lebih terpuruk dari orang fakir. Oleh Imâm Mâlik dan sebagian ulama Malikiyah berpendapat kedua kelompok inilah yang berhak menerima zakât fitrah (Mughniyah, 2011).

Uraian di atas memperlihatkan bahwa Imâm Mâlik dan sebagian ulama Malikiyah lebih mengkhususkan mustahik zakat fitrah berdasarkan petunjuk Rasûlullâh SAW dalam haditsnya, dan juga didasarkan pada alasan akan pemenuhan kebutuhan kaum fakir dan miskin di hari kemenangan 'Idul Fitri sebagai hari kemenangan bagi seluruh umat Islam. Menurut hemat penulis, pendapat yang mengkhususkan mustahiq zakât fitrah untuk kelompok alfuqarâ' dan al-masâkîn ini diduga kuat lebih tepat untuk diikuti, karena disamping didukung oleh dalil naqli yang kuat, juga dapat dinilai lebih relevan dengan tujuan dan hikmah dari disyariatkannya zakat fihrah bagi semua umat Islam.

\section{KESIMPULAN}

1. Berbeda dengan pendapat jumhur ulama yang menyatakan bahwa mustahiq zakat fitrah adalah asnaf yang delapan mustahiq zakat mall sebagaimana titah Allâh SWT yang termaktub dalam QS. Al-Taubah ayat 60. Sementara itu, Imam Malik dan sebagian ulama malikiyah lebih mengkhususkan mustahiq zakat fitrah kepada dua kelompok saja sepertinya apa yang terdapat pada hadits Rasûlullâh SAW yang diriwatkan oleh sahabat Ibnu 'Abbas yang berisikan tentang hikmah, mustahiq, dan waktu pelaksanaan zakat fitrah itu sendiri. Berdasarkan ini Imâm Mâlik dan juga sebagian ulama Malikiyah berpendapat tentang akan adanya keharusan memberikan kehidupan yang layak dan ikut berbahagia di hari 'idul fitri bagi semua kaum fakîr dan miskîn karena telah tercukupinya kebutuhan hidup mereka.

2. Dikhususkan mustahiq zakât fitrah kepada kelompok fakir dan miskin saja tentu akan dapat merealisasikan hikmah zakat fitrah, yaitu membersihkan orang yang berpuasa dari perkataan yang sia-sia dan tidak

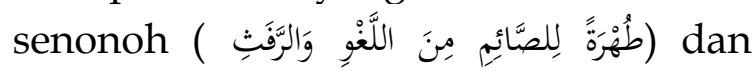
dapat memberikan makanan atau bahkan penghidupan yang layak bagi fakir miskin (وَطُعْمَة لِلْمَسَاكِينِ ).

3. Selanjutnya dengan berpegang kepada 
pendapat Imam Malik dalam hal mustahiq zakat fitrah diduga kuat akan lebih relevan dan bernilai mashlahah bagi ummat Islam, terutama bagi mereka yang masih tergolong fakir dan miskin, untuk juga bisa berkemampuan melaksanakan kewajiban zakat fitrah, serta mendapatkan hikmah dari pelaksanaan zakat fitrah (bersihnya alshâimîn dari perkataan yang sia-sia dan tidak berguna, dan hadirnya makanan dan kehidupan yang layak bagi semua umat Islam).

\section{DAFTAR KEPUSTAKAAN}

'Abîd, al-H. K. (n.d.). Fiqh al-Ibâdât ala alMazâhib al-Mâliki.

Al-Damsyiqi, A. al-F. I. ibn K. (1997). Tafsir al-Qur'an al-'Adzim. Beirut: Darul al-Fikr.

Al-Qardhowi, Y. (1999). Hukum Zakat. Bogor: Lintera Antar Nusa.

Al-Syurbasi, A. (1991). Sejarah dan Biografi Empat Imam Mazhab. Jakarta: Bumi Aksara.

Al-Zuhaili, W. (1997). Zakat Kajian Berbagai Mazhab. Terjemahan. Bandung: PT.
Remaja Rosda Karya.

Aziz, A. (2003). Ensiklopedi Hukum Islam. (Dahlan, Ed.). Jakarta: PT. Ichtiar Baru Van hoeve.

Hafidhuddin, D. (2014). Reinterpretasi Pendayagunaan ZIS Menuju Efektivitas Pemanfaatan Zakat, Infak, Sedekah. Jakarta: Piramedia.

Hasan, M. A. (2006). Zakat dan Infak: Salah Satu Solusi Mengatasi Problema Sosial di Indonesia. Jakarta: Kencana.

Mughniyah, M. J. (2011). Al-Figh 'alâ alMazâhib al-Khamsah. Terjemahan oleh Afif Muhammad.

Rahman, Z. (1995). Kajian Sunnah Nabi SAW sebagai Sumber Hukum Islam. Jakarta: Pedoman Ilmu Jaya.

Sabiq, S. (1978). Fiqh al-Sunnah. Terjemahan oleh Mahyuddin Syaf. Figh Sunnah. Bandung: Alma'arif.

Syarifuddin, A. (2003). Garis-garis Besar Figh. Bogor: Kencana.

Yanggo, H. T. (1997). Pengantar Perbandingan Madzhab. Jakarta: Logos. 